\title{
Administrative Changes in Qin Village
}

1955 Two primary agricultural production cooperatives were created in Qin village.

1956 The Qindian Advanced Agricultural Production Cooperative was created, which included two production teams in Qin village and another two teams in the neighboring Ji village.

1958 The Qindian Advanced Agricultural Production Cooperative was renamed the Qindian Company of the Baozhuang Brigade of Shiyan People's Commune.

1959 The Qindian Company was renamed the Suqin Brigade of Qindong People's Commune. The company had five production teams, including one in Qin village (the No. 5 team).

1960 The five teams of the Suqin Brigade were split into eight production teams, including six in Su village, one in Ji village, and one in Qin village (the No. 8 team).

1966 The Suqin Brigade was renamed the Zhigang Brigade. The No. 8 production team of the Suqin Brigade was divided into two new teams, namely the No. 8 and No. 11 teams of the Zhigang Brigade.

1981 The three teams in Ji village and two production teams in Qin village were separated from the six teams in Su village to form the Qindian Brigade. The No. 11 team of the Zhigang Brigade became the No. 5 team of the Qindian Brigade.

1984 The No. 5 team of the Qindian Brigade was renamed the No. 5 Group of Qin Village. 